\title{
EL RETRAT: UNA PROPOSTA PER TREBALLAR L'ART AL MUSEU D'ART MODERN DE TARRAGONA
}

\author{
Núria Serra Medina. Museu d'Art Modern de Tarragona. Diputació de Tarragona
}

Una activitat pedagògica es pot comparar amb una representació teatral, on cadascun dels personatges que hi participen adopten un paper. El museu és l'escenari, i el personal que hi treballa, els actors. Els alumnes passen a ser el públic, i els professors, com a productors, tenen l'obligació de saber i informar-se dels recursos que els poden oferir aquells actors i com és l'espai on es representarà l'acció.

Diem que és important, o que és una obligació per part dels docents, saber què és el que els poden oferir, perquè en molts casos depèn d'ells l'èxit d'una visita.

Estimular els alumnes des de l'aula realitzant una activitat prèvia a la visita al museu els ajuda a connectar o a crear un vincle invisible, que servirà per a apropar-los a les obres i a sentir el museu com un indret accessible i familiar.

El Museu d'Art Modern de Tarragona compta amb diverses activitats relacionades amb les seves obres i adaptades a cada nivell educatiu, com és el cas de l'activitat del retrat.

Es tracta d'una de les activitats més sol-licitades al museu per la seva explicació, els conceptes que s'hi imparteixen, l'exercici que acaben realitzant els alumnes i la satisfacció que provoca observar els resultats del seu treball.

En aquest article exposarem com es desenvolupa l'activitat entorn del retrat descrivint com la vam dur a terme al museu amb els alumnes d'educació infantil del CEIP Pràctiques.

\section{Característiques de l'activitat}

L'activitat s'ha pensat per a un màxim de 25 a 30 alumnes, amb una durada d'una hora i mitja a dues hores. La recepció dels alumnes es fa a la sala d'actes del museu, on se'ls dóna la benvinguda i se'ls projecta l'obra Hermana I (1997), de la pintora Barbara Stammel. Amb la formulació de diverses preguntes -com "Què és, un home o una dona?", "Com deu ser l'obra, gran o petita?-, es pretén iniciar els alumnes en l'activitat. Aquests interrogants es desvelaran quan es trobin amb l'obra a les diferents sales.

Referent a la metodologia de treball, es busca l'observació directa de les obres en el seu espai expositiu concret, establint les diferents pautes de treball i la planificació de la visita conjuntament amb els docents, i treballant aspectes formals $\mathrm{i}$ tècnics, així com el concepte de l'obra.

El recorregut pel museu s'inicia per les sales, on s'observen diferents tipus de retrats, la fotografia de l'escultor Julio Antonio, el seu autoretrat, l'escultura en bronze de Maria la Gitana, etc. El fet de buscar el retrat per les sales del museu i el descobriment o troballa de l'obra Hermana I els emociona, els situa en l'acció i els fa esperar expectants l'inici de l'activitat.

Pel que fa als materials necessaris, cal disposar de marcs de cartró per simular un retrat real de l'alumne i veure diferents tipus d'enquadrament, colors, llapis, fulls amb el logotip del museu, gomes, uns panells amb diverses fotografies d'un mateix personatge (p.e. la reina Isabel II d'Anglaterra), una reproducció de l'obra de Barbara Stammel en petit (que manipulem i colloquem sobre diversos fons), un llum que senvirà per a fer una explicació sobre la importància de la llum i les ombres, targetes de colors que utilitzem per parlar de la barreja de colors, i un cavallet i un gran panell, que utilitzarem per penjar les obres dels petits artistes.

\section{Desenvolupament de l'activitat}

Una vegada a la sala, els alumnes seuen davant de l'obra sobre unes estores preparades per a ells. S'inicia un diàleg que busca la participació dels alumnes. Mitjançant diverses preguntes es treballa:

- Les parts de la cara. Es repassen totes les parts o elements que conformen la cara. Observem la cara i diem que hi ha diferents tipus de rostres: allargats, rodons, quadrats, etc. També aprenem paraules noves: M (museu): Com es diu aquesta pell dels ulls que puja i baixa?

$A_{1}$ (alumne): Pestanya!

M: No, les pestanyes són els pelets que tenim aquí, als ulls. Aquesta pell que sembla una persiana que s'obre i es tanca.

$A_{2}$ : No ho sé.

M: Tanqueu tothom els ulls i ara obriu-los. Sabeu com es diu? Això són les "par-pe-lles". A veure com ho dieu vosaltres?

$\mathrm{A}_{3}$ : Par-pe-lles.

- És un noi o una noia? Aquesta pregunta obté ambdues respostes per part dels alumnes. Tot i saber 


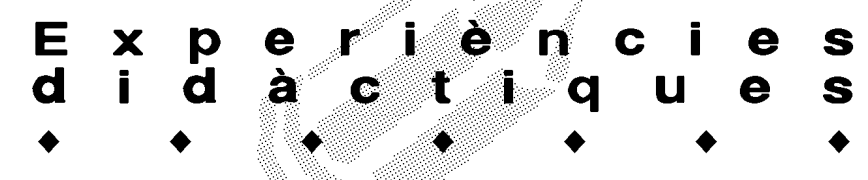

el títol de l'obra, els trets facials, la frontalitat de l'obra i el color del retrat confonen els alumnes a I'hora de determinar si és un home o una dona.

- Les expressions. Observem l'obra i intentem identificar quina és la seva expressió. També preguntem què creuen que pot estar pensant i si parlés què ens diria; d'aquesta forma iniciem un diàleg entre l'obra i els nens i nenes:

$\mathrm{M}$ : Què deu estar pensant?

$A_{1}$ : No ho sé.

M: Si pogués parlar, què us diria?

$\mathrm{A}_{2}$ : Hola.

$\mathrm{M}$ : D'on sou?

$\mathrm{A}_{3}$ : Què feu aquí?

- Bidimensionalitat de l'obra. Un quadre no es pot mirar des de diferents angles. Així que no veiem l'obra per darrere, sinó únicament pel davant: no podem saber com té els cabells (llargs, curts, amb cua, amb una trena...).

- El color. Se'ls mostren els colors freds i calents. Utilitzem unes targetes per saber si els alumnes saben fer barreges de colors i comprovem amb quins colors ha estat feta l'obra.

M: Sabeu fer barreja de colors?

$A_{1}:$ Sí!

M: Qui em pot dir com es fa el color taronja?

$\mathrm{A}_{2}$ : Amb el vermell $i$ el rosa!

$\mathrm{M}:$ No.

$\mathrm{A}_{3}:$ Amb el groc i el vermell!

M: Molt bé. l el verd? Com es pot fer el verd?

$\mathrm{A}_{4}$ : Amb el blau i el groc!

M: Molt bé. Sabeu algun color més?
$\mathrm{A}_{5}:$ Sí! El gris!

$\mathrm{M}$ : I com es fa el gris?

$\mathrm{A}_{6}:$ Amb el blanc i el negre!

M: Molt bé. I si hi posem més quantitat de negre o menys quantitat sortirà un gris més fosc o més clar.

- Com ha estat pintada l'obra. Explicació que l'artista ha utilitzat pinzells i també els seus propis dits per sucar la pintura i aplicar-la a la tela. Sobre el cap i al costat dret de la figura observem una mena d'esquitx que crida l'atenció dels alumnes:

M: Què és allò que té damunt del cap?

$A_{1}$ : Sembla una esquitxada.

$A_{2}$ : Ho ha embrutat.

M: Oi que sembla una esquitxada? Doncs l'artista ha deixat que la pintura regalimi sobre l'obra.

$\mathrm{A}_{3}:$ Per què?

$\mathrm{M}$ : Això és una tècnica que utilitzen els artistes i que es diu driping i consisteix a sucar el pinzell amb pintura $i$ esquitxar-lo sobre l'obra. Un senyor que era un pintor i es deia Pollock ho va inventar i feia les seves obres d'art esquitxant pintura sobre el quadre.

- La llum i l'ombra. Quatre o cinc nens surten davant dels companys. Es procura que la forma de l'oval del rostre sigui diferent i també el color de la pell, i aquí s'inicia un debat sobre quin creuen que és el color de la pell, fins a arribar a la conclusió que cadascú tenim el nostre propi color, sigui blanc, negre, groc o marró. Apropem un llum a un costat del rostre dels alumnes: observem com els canvia el color de la cara, dels ulls i dels cabells que són il.luminats, i com influeix la llum il'ombra en les persones i els objectes segons com s'apliqui.

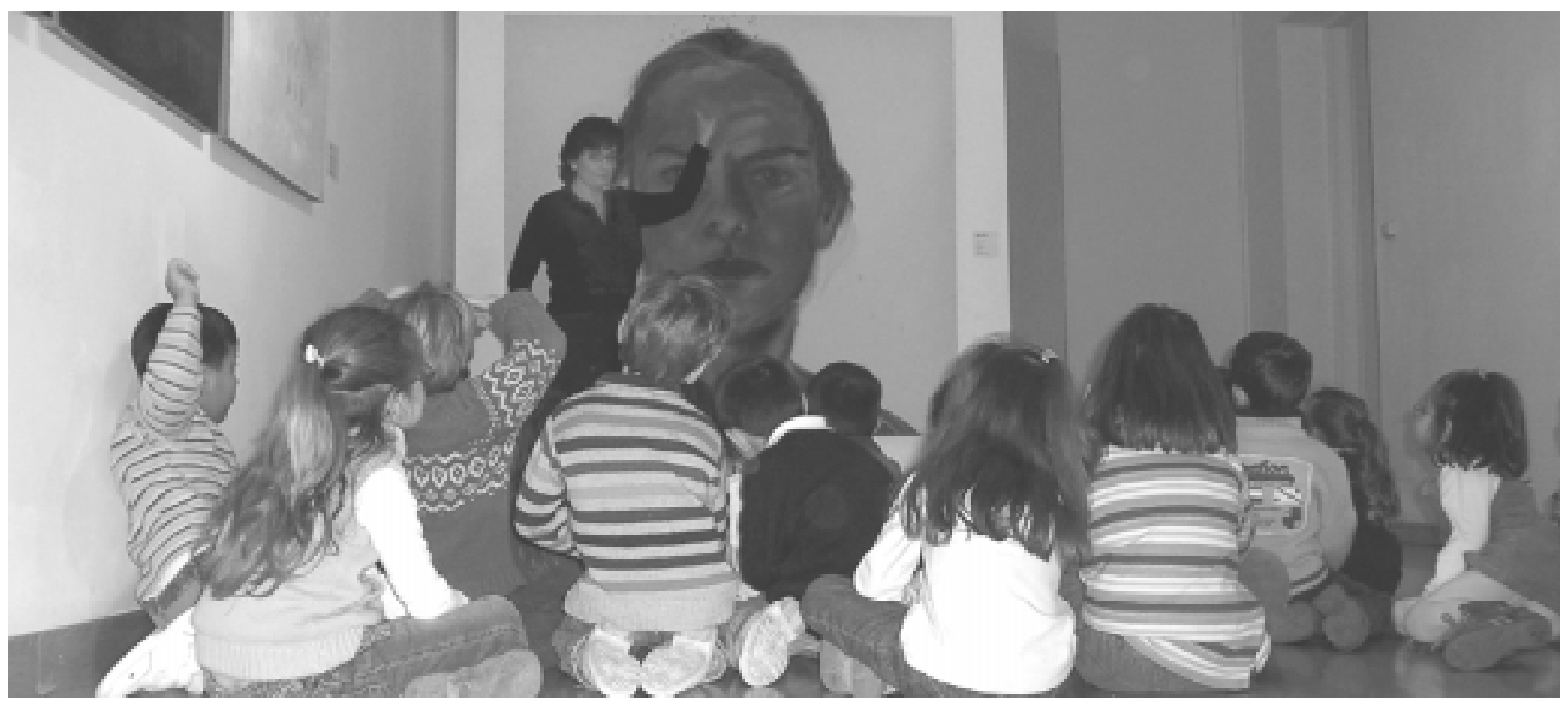




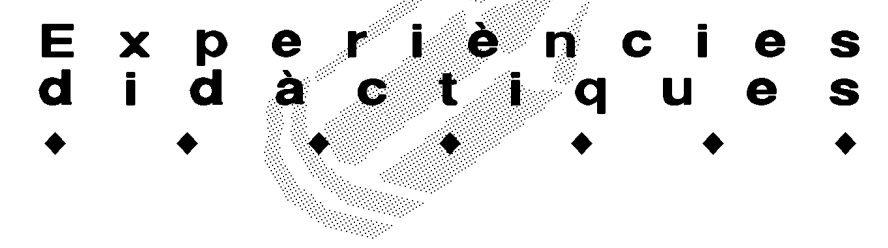

M: Sabeu que gràcies a la llum podem veure els colors?

$\mathrm{A}_{1}:$ Ah sí?

M: Penseu quan a la nit aneu a dormir i la mare baixa la persiana: oi que es fa fosc?

$A_{2}$ : Jo deixo encès el llum del passadís!

$A_{3}$ : Jo tinc un llumet a la tauleta!

M: Sí, però si no hi hagués cap llum a l'habitació, al matí quan la mare obre la finestra, oi que tornaríem a veure l'habitació plena de colors?

$\mathrm{A}_{4}$ : Sí!

- Observem si hi ha elements que acompanyin la figura. No sabem res d'ella, no utilitza cap atribut que la identifiqui amb la seva professió. A què es pot dedicar?

- Aplicació d'una reproducció de l'obra sobre diferents fons. A l'obra original la figura està sola, però si la col-loquem sobre un fons d'una ciutat, un bosc, una platja, etc., quina història podem inventar a partir d'aquí?

Un cop feta l'observació completa de l'obra, utilitzem el panell per observar diverses fotografies i dibuixos de la reina Isabel II d'Anglaterra. En una fotografia apareix amb corona; en unes altres amb barret o amb mocador, en una caricatura, en un retrat de Lucien Freud, en un bitllet, etc. Preguntem als alumnes quina creuen que és una reina. Evidentment assenyalen les fotografies que tenen corona, i sobre la resta fan les seves pròpies aportacions. Un alumne creu que la dona de la fotografia que porta un mocador és la castanyera; un altre diu que és una àvia, etc. Però no arriben a concloure que es tracta de diversos retrats d'una mateixa persona fins que finalment se'ls ho diu. D'aquesta forma establim de nou un diàleg amb la gran varietat de retrats que es poden arribar a fer d'una mateixa persona:

M: Oi que quan aneu a un casament o a una festa no aneu vestits igual que ara?

$A_{1}$ : No, la mare em posa un vestit.

$\mathrm{A}_{2}$ : Sí, i les sabates de mudar.

M: És clar, i us posa ben macos. Doncs si agafeu a casa un àlbum de fotografies i us mireu a vosaltres o als pares, veureu com les persones van canviant al llarg del temps i segons l'ocasió que sigui van vestits d'una forma o d'una altra. Això li ha passat a aquesta senyora. Veiem retrats d'ella en diferents èpoques de la seva vida, o vestida de diverses maneres, però sempre és la mateixa persona.

\section{Exercici pràctic}

Finalment l'alumne ha d'expressar sobre el paper moltes de les coses que ha après. Es demana als alumnes que facin un retrat, i per això s'han de posar en parelles. En aquesta activitat treballen el respecte vers el company; la capacitat d'observació es veu aguditzada i els alumnes aprenen a fer un ús adient del llapis i la goma: no han d'aplicar una pressió excessiva al llapis, perquè si s'equivoquen, el traç serà tan fort que en esborrar arrugaran el paper.

Abans de començar a treballar es donen unes pautes. Han de començar a treballar dibuixant l'oval, que ha d'ocupar tot el full -no un oval petit, on no càpiguen totes les parts de la cara-. Es recalca molt als alumnes la necessitat de dibuixar totes les parts de la cara, començant per dividir-la en diferents "registres" per tal de deixar un espai per al front; un altre espai per als ulls amb les celles, les parpelles, pestanyes, nineta, iris, etc., i un altre espai per al nas, els llavis. És important que es fixin en els trets característics del companys: si tenen pigues a la cara, el color dels ulls, dels cabells, de la pell, si porten ulleres, una cua, etc.

Quan han acabat el dibuix en llapis, es passa a donar color a l'obra. Els alumnes pinten el color de la pell segons la dels seus companys, i alguns de forma voluntària volen aplicar llums i ombres al seu retrat i agafen un color diferent o més fort per pintar la meitat de la cara.

Una vegada finalitzats els retrats, es col-loquen un al costat de l'altre perquè la resta dels companys els puguin observar. D'aquesta observació sorgeix un diàleg. Els alumnes expressen quins són els retrats que més els agraden, identifiquen els nens que hi són representats i queden satisfets del seu treball i que aquests quedin exposats a les sales del museu fins que acaba l'activitat.

\section{El treball a l'escola i els beneficis de l'experiència}

En un inici comentàvem la importància del treball previ a l'escola. És igualment important el treball posterior. Aprofitar allò que s'ha treballat al museu i aplicar-ho a les aules ajuda que els continguts que s'han après es mantinguin en la memòria de l'alumne i que no quedin en una simple experiència.

El treball a l'escola també suposa una satisfacció per al servei pedagògic del museu, perquè en el cas de l'escola de Pràctiques el museu es desplaça fins a les aules per veure com els alumnes han treballat després de la visita.

La interacció que es crea entre el museu i l'escola és molt important. S'estableix un diàleg, un feedback per a un aprenentatge mutu, perquè no són els alumnes els únics que es beneficien de la visita: també ho fan els professors i per extensió el museu i els seus pedagogs, que diàriament aprenen d'aquelles preguntes i observacions dels alumnes per així poder oferir un millor servei a totes les persones que visiten el Museu d'Art Modern de Tarragona. 